\title{
Growth Responses of Avicennia germinans and Batis maritima Seedlings to Weathered Light Sweet Crude Oil Applied to Soil and Aboveground Tissues
}

\section{William J. Heintz}

Nicholls State University

Jonathan Willis ( $\nabla$ jonathan.willis@nicholls.edu )

Nicholls State University https://orcid.org/0000-0002-8140-4896

\section{Research Article}

Keywords: coastal wetlands, salt marsh, mangrove, oil spills, petroleum, contamination

Posted Date: August 23rd, 2021

DOl: https://doi.org/10.21203/rs.3.rs-713583/v1

License: (c) (1) This work is licensed under a Creative Commons Attribution 4.0 International License.

Read Full License 


\section{Abstract}

Oil spills are a significant stressor to coastal and maritime environments worldwide. The growth responses of Batis maritima and Avicennia germinans seedlings to weathered Deepwater Horizon oiling were assessed through a mesocosm study using a factorial arrangement of 4 soil oiling levels $\left(0 \mathrm{~L} \mathrm{~m}^{-2}, 1\right.$ $\left.\mathrm{L} \mathrm{m}^{-2}, 2 \mathrm{~L} \mathrm{~m}^{-2}, 4 \mathrm{~L} \mathrm{~m}^{-2}\right) \times 3$ tissue oiling levels ( $0 \%$ of stem height, $50 \%$ of stem height, $100 \%$ of stem height). Overall, growth metrics of $B$. maritima displayed much greater sensitivity to both tissue and soil oiling than A. germinans, which exhibited a relatively high tolerance to both routes of oiling exposure. Batis maritima in the $4 \mathrm{~L} \mathrm{~m}^{-2}$ soil oiling treatment demonstrated significant reductions in cumulative stem height and leaf number, whereas no significant effects of soil oiling on A. germinans were detected. This was reflected in end of the study biomass partitioning, where total aboveground and live aboveground biomass were significantly reduced for $B$. maritima with $4 \mathrm{~L} \mathrm{~m}^{-2}$ soil oiling, but no impacts to $A$. germinans were found. Tissue oiling of $100 \%$ did appear to initially reduce $B$. maritima stem diameter, but no effect of tissue oiling was discerned on biomass partitioning, suggesting that there were no impacts to integrated growth. These findings suggest that $B$. maritima would be more severely affected by heavy soil oiling than $A$. germinans.

\section{Introduction}

Salt marshes are valuable habitats that provide a number of ecosystem services, including coastal erosion mitigation, carbon sequestration, water quality enhancement, and faunal support (Pennings and Bertness 2001; Barbier et al. 2011; Duke 2016; Gorman and Turra 2016; CPRA 2017). Vegetation in these salt marshes are subjected to a number of environmental stressors, including elevated flooding, anoxic soils, and increased salinity (Pennings and Bertness 2001; Alleman and Hester 2010; Lonard et al. 2017). However, human activities can present additional stressors to salt marsh vegetation, including those associated with oil spills (Lin and Mendelssohn 2012). Thousands of oil spills occur in waters of the United States (U.S.) annually, and although the vast majority of these incidents are small ( $<159 \mathrm{~L}), 44$ spills greater than 1.59 million L in volume have occurred in U.S. waters since 1969 (National Oceanic and Atmospheric Administration 2017). Oil spills in salt marshes are particularly problematic not only because of direct physical and chemical impact to biota, but also because of the persistence of oil in flooded soils and the fragility of these habitats precluding subsequent clean up (Pezeshki et al. 2000; Michel and Rutherford 2013). The prevalence of oil spills in coastal areas underscores the need to understand how oiling impacts the valuable species occurring in these important habitats.

Oil spills are relatively frequent in areas where large volumes of petrochemical products are extracted and refined, such as the northern Gulf of Mexico. Coastal wetlands along the northern Gulf of Mexico experienced extensive oiling following the Deepwater Horizon spill on April 20, 2010 (Nixon et al. 2016), which was the largest marine oil spill in the U.S. to date (Mendelssohn et al. 2012; Michel et al. 2013). The Deepwater Horizon spill impacted coastal wetland vegetation in Louisiana (Hester et al. 2016), as well as in Mississippi and Alabama (Willis et al. 2016). The spill released more than 760 million $L$ of 
MC252, a light sweet crude oil, over a 3-month period and resulted in more than 1,040 km of coastal marsh shorelines being oiled, with more than $208 \mathrm{~km}$ of this shoreline categorized as moderately to heavily oiled (Lin and Mendelssohn 2012; Nixon et al. 2016). A recent investigation into the persistence of $D W H$ petroleum residues in previously oiled Louisiana marshes revealed that oiling contamination continues to be elevated by an order of magnitude over eight years since the spill's occurrence (Turner et al. 2019). Because of the critical roles played by coastal wetlands and the threats posed by oil spills, enhancing the understanding of the effects of oiling on salt marsh vegetation continues to be an important topic of study.

Avicennia germinans (L.) L. (black mangrove) and Batis maritima L. (marine saltwort) are common constituents of high marshes of the subtropical Gulf of Mexico, including coastal Louisiana (Alleman and Hester 2010; Lonard et al. 2011). Avicennia germinans occurs in the more southern, warmer saline marshes, such that the species has its northernmost boundaries in the Americas along the barrier islands and salt marshes of Louisiana's Gulf of Mexico coast (Alleman and Hester 2010) and in the Guana Tolomato Matanzas National Estuarine Research Reserve of Florida's Atlantic coast (Devaney et al. 2017). Batis maritima has a wide distribution that includes high marsh areas and ridges in the coastal areas of the Gulf of Mexico (Lonard et al. 2011). Although Spartina alterniflora (smooth cordgrass) is the dominant macrophyte in salt marshes of Louisiana, A. germinans is often present as a codominant or subdominant species in these areas (Hester et al. 2005). Batis maritima typically occurs at relatively high elevations in salt marshes throughout the Gulf of Mexico coast (Rasser et al. 2013). However, both $A$. germinans and $B$. maritima are commonly present in the high marsh of coastal Louisiana (Hester et al. 2005; Lonard et al. 2017). Avicennia germinans, B. maritima, and other plant species of mangrove ecosystems in coastal Louisiana and throughout the Gulf of Mexico contribute to important ecosystem services, including protection from erosion, carbon export and sequestration, nursery habitats for fishes and crustaceans, and resources for humans (Katherisan and Bingham 2001; Alongi 2002; Nagelkerken et al. 2008; Everard et al. 2014; Lee et al. 2014; Gormand and Turra 2016).

Laboratory studies of mangrove oiling have yielded useful information about survival and growth responses. Getter et al. (1983) compared effects of unweathered oil and/or dispersants on A. germinans and $R$. mangle seedlings and demonstrated that $A$. germinans is more sensitive to oils, dispersants, and oil-dispersant combinations than $R$. mangle. Getter et al. (1983) noted that $A$. germinans osmoregulates by taking up solutes into the roots then excreting solutes through leaf tissue, with oil included in the uptake and becoming deposited on the leaves, whereas $R$. mangle excludes this root uptake (Getter et al. 1983). In the study, effects varied among groups treated variously with a light crude oil, a heavy distillate oil, and a light distillate oil, with lighter oils showing increased effects (leaf shape and width) overall, though the lower concentrations of No. 2 fuel oil and bunker $C$ fuel oil had greater growth rates and foliage production in A. germinans than untreated controls. Combining dispersant with oil increased effects in some instances. Getter and Baca (1984) provided further data regarding impacts of unweathered oil and/or dispersant on $R$. mangle, reporting that root-dosing by injection into the soil had lesser effects than tissue dosing, and also that seedlings of $A$. germinans and $R$. mangle obtained from 
areas that have been chronically oiled grew more foliage in response to Light Arabian oil. The authors proposed that previous oil exposure may result in an adaptive response (Getter and Baca 1984).

In another controlled study, no A. germinans seedlings exposed to fresh motor oil as a one-time application of $120 \mathrm{~mL}$ or $15 \mathrm{~mL}$ per week survived beyond a few weeks in a 59-week study, while $75 \%$ of R. mangle survived (Proffitt et al. 1995). A one-time oiling treatment under hot and bright outdoor conditions (as opposed to air-conditioned and diffusely lit laboratory conditions) yielded the greatest mortality (Proffitt et al. 1995). Additionally, acute treatment of $A$. germinans seedlings with $120 \mathrm{~mL}$ of Bonny Light crude oil placed on the soil surface of the base of the seedling showed episodic mortality, with $100 \%$ survival at 2 weeks, $70 \%$ between weeks 3 and $4,60 \%$ between weeks 5 and $10,50 \%$ at week 11 , and $30 \%$ between weeks 12 and 16 (Chindah et al. 2011). Chronic treatment with $15 \mathrm{~mL}$ weekly resulted in reduced survival in weeks 13 and 14, stabilizing in week 15 (Chindah et al. 2011).

Hughes et al. (2018) studied the effects of weathered Louisiana sweet crude oil on mesocosms of $A$. germinans (one-year-old seedlings), S. alterniflora, and combined A. germinans and S. alterniflora assemblages. Oiling treatments of $8 \mathrm{~L} \mathrm{~m}^{-2}$ of a weathered crude oil was applied and drained for 5 days, diurnal tide actions were simulated, and response variables were followed for 1 year. Oiling adversely impacted both species, and mixing the species provided no benefit for $S$. alterniflora. However, the mixed community showed reductions in the negative effects of oiling for $A$. germinans. Reduction in $A$. germinans survival and belowground biomass were mitigated to $12 \%$ from $21 \%$ and to $19 \%$ from $71 \%$ in the mixed species condition compared to $A$. germinans alone.

The frequency of oiling in coastal wetland habitats necessitates studies that provide insight into how oiling exposure impacts the health and subsequent recovery of specific coastal wetland vegetation species. The effects of oiling exposure on $A$. germinans have been addressed in a number of observational and controlled studies (Getter et al. 1983; Proffit et al. 1995; Chindah et al. 2011; Hughes et al. 2018). However, knowledge gaps exist in regard to the interactive effect of soil and aboveground tissue oiling for $A$. germinans seedlings. Further, the effect of oiling exposure on $B$. maritima has not been experimentally assessed at the time of this writing. The purpose of this research is to expand the knowledge base of oiling impacts on two high marsh vegetation species relevant to the Gulf of Mexico in order to facilitate coastal management.

\section{Materials And Methods}

Seedlings of A. germinans and B. maritima were collected with intact adjacent soil in April 2018 from the Caminada Moreau Headland, LA. The plants were then transported to the Nicholls State University Farm greenhouse facility and transplanted into $15 \mathrm{~cm}$ (diameter) by $17 \mathrm{~cm}$ (height) polyethelene pots that were individually placed into $4.73 \mathrm{~L}$ polyethelene reservoirs. Reservoir water levels were maintained $10 \mathrm{~cm}$ below the soil surface of experimental pots for the duration of the study, with salinities maintained at 18 psu using commercial sea salt (Instant Ocean Spectrum Brands, Blacksburg, VA). Salinity levels in reservoirs were checked biweekly using a handheld meter, and adjusted to 18 psu as necessary. 
This study employed a 2 species (A. germinans, B. maritima) $x 4$ soil oiling levels $\left(0 \mathrm{~L} \mathrm{~m}^{-2}, 1 \mathrm{~L} \mathrm{~m}^{-2}, 2 \mathrm{~L} \mathrm{~m}^{-2}\right.$ , $4 \mathrm{~L} \mathrm{~m}^{-2}$ ) $\times 3$ tissue oiling levels ( $0 \%$ of stem height, $50 \%$ of stem height, $100 \%$ of stem height) completely randomized factorial design with 4 replicates for a total of 96 experimental units. Each experimental unit consisted of a pot containing a single plant of the appropriate species. Experimental plantings were allowed to acclimate for two weeks; thereafter, weathered MC252 oil was applied to achieve oiling treatments. The MC252 oil had previously been weathered by aerating with bubblers in a fume hood until oil volume was reduced to $50 \%$ of the initial. Aboveground tissue oiling treatments were applied by dipping a nitrile-gloved hand into a beaker of oil and applying a thin film of oil to the appropriate vertical extent of the plant. Soil oiling treatments were accomplished by individually draining the reservoir floodwaters of experimental units into an empty reservoir container, mixing in the appropriate concentration of oiling, and gently pouring the oil-water mixture directly onto the soil surface of the experimental units. After soil oiling, experimental water levels were restored to the reservoirs containing the pots. The study duration was 5 months, with the experiment initiated in early June 2018 and with harvesting in late October 2018.

Immediately prior to the initiation of the experimental treatments, cumulative stem height, stem diameter, leaf number, and visual chlorosis were determined for all experimental units. Cumulative stem height typically included one stem for $A$. germinans units but often involved multiple stems for units of $B$. maritima, with those multiple stem heights summed into one measurement. Stem height was measured from the soil surface to the highest point on each stem using a meter stick and recorded to the nearest $\mathrm{mm}$. Stem diameter was measured to the nearest $\mathrm{mm}$ using calipers on the main stem $5 \mathrm{~cm}$ above the soil surface. Chlorosis was visually estimated using a scale developed by Mendelssohn et al. (1990): no impact (naturally speckled chlorosis); trace impact (intensely speckled chlorosis); light impact (50\% or less yellowing); medium impact (more than $50 \%$ yellowing); heavy impact (all vegetation dead). Cumulative stem height and stem diameter, mortality, leaf number, and visual chlorosis were determined biweekly for both species.

At the conclusion of the study all leaves of $A$. germinans were harvested, rinsed, blotted dry, then scanned into a digital image using a flatbed scanner (Canon LiDE 110, Melville, NY). A small ruler was included in each scanned image for determination of scale. Digital images were analyzed using ImageJ software (Abramoff et al. 2004) to estimate individual leaf area. Following scanning, the leaves were placed into individual, numbered manila coin envelopes, dried to a constant weight at $65^{\circ} \mathrm{C}$, and individual leaf weights determined. Specific leaf area (leaf area/leaf mass) was then calculated on a whole plant basis. For all experimental units, aboveground biomass was clipped at the soil surface using shears, rinsed of debris above a screen, partitioned into live and dead components, and dried to a constant mass before weighing.

Data were analyzed using an ANOVA framework with a priori contrasts in R 3.6. For metrics measured at one point in time (e.g., biomass metrics collected at harvest), univariate factorial ANOVAs were executed using the aov command in R. For metrics collected over time (e.g., cumulative stem height), a mixed 
model factorial ANOVA approach with time as the random effect was implemented using the Ime command within the nlme package.

\section{Results}

Significant main effects of time (Fig. 1; $F=114.1, P<0.0001$ ) and species (Fig. 1; $F=38.0, P<0.0001$ ) were detected for repeated cumulative stem height measurements. However, significant interactions of time and species (Fig. 1; F= 47.2, $P<0.0001$ ), time and soil oiling (Fig. 1; $F=4.3, P=0.0054$ ), and time, species, and soil oiling (Fig. 1; F= 2.7, P= 0.0477) were also detected. Interestingly, the significant interaction of time, species, and soil oiling appears to reflect the much slower rate of increase in cumulative stem height for $B$. maritima in the $4 \mathrm{~L} \mathrm{~m}^{-2}$ soil oiling treatment compared to the control, whereas no difference in $A$. germinans cumulative stem height was seen among treatments. This notable impact to $B$. maritima cumulative stem height in the $4 \mathrm{~L} \mathrm{~m}^{-2}$ soil oiling treatment is likely also responsible for the significant time and soil oiling interaction. The greater increase in cumulative stem height for $B$. maritima over time compared to A. germinans, which was expected given B. maritima's production of multiple shoots, appears to be driving the significant interaction of time and species, as well as the significant main effects of time and species.

Avicennia germinans exhibited greater stem diameter than $B$. maritima throughout the course of the experiment (Fig. 2; F= 76.7, $P<0.0001$ ). The effect of time (Fig. 2; $F=28.1, P<0.0001$ ) as well as interactions of time and species (Fig. 2; F=14.0, $P=0.0002$ ) were both significant, and appear to represent growth over time and interspecific variation in growth over time, respectively. Time and soil oiling approached significance (Fig. 2; F= 2.6, $P=0.0531$ ), and time and tissue oiling (Fig. 2; F= 3.9, P= 0.0209) was also significant for the repeated stem diameter measurements. These interactions appear to represent reductions in average stem diameter for Batis maritima for the highest dosage of soil oiling (4 $\mathrm{L}$ $\mathrm{m}^{-2}$ ) and level of tissue oiling (100\%), while $A$. germinans stem diameter was apparently unaffected by these treatment levels.

Batis maritima had a significantly greater increase in leaf number than A. germinans (Fig. 3; F=5.5, $\mathrm{P}=0.022)$. However, no effect of soil oiling, tissue oiling, or any interactions were detected for leaf number for either species. Batis maritima exhibited a higher visually-estimated chlorotic index than $A$. germinans (Fig. 4; $\mathrm{F}=5.8, \mathrm{P}=0.019$ ), but this likely reflects the normal yellow coloration exhibited by $B$. maritima. No effect of soil oiling, tissue oiling, or any interactions thereof were detected for chlorotic index.

A significant effect of species was detected for both total aboveground biomass (Fig. 5; $F=7.21, P=0.009$ ) and live aboveground biomass (Fig. $6 ; \mathrm{F}=4.80, \mathrm{P}=0.032$ ) with $B$. maritima having slightly higher total and live aboveground biomass compared to $A$. germinans. No overall effect of soil oiling, tissue oiling, or any interactions were detected for total aboveground biomass or live aboveground biomass for $A$. germinans. However, for $B$. maritima the a priori contrast of $0 \mathrm{~L} \mathrm{~m}^{-2}$ with $4 \mathrm{~L} \mathrm{~m}^{-2}$ revealed significantly lower total aboveground biomass (Fig. 5, Contrast $F=1.57, p=0.0163$ ) and total live aboveground biomass (Fig. 6, 
Contrast $\mathrm{F}=1.67, \mathrm{p}=0.0065$ ). Avicennia germinans specific leaf area (Fig. 7; $\mathrm{F}=3.976 ; \mathrm{P}=0.029$ ), was significantly higher for the $100 \%$ tissue oiling level compared to no tissue oiling, averaged across soil oiling treatments.

\section{Discussion}

Oil spills are among the significant threats to coastal marsh regions, as was recently highlighted by the Deepwater Horizon incident, the largest marine oil spill thus far in U.S. waters (Mendelssohn et al. 2012). The research presented herein reveals differential tolerance by two important Gulf of Mexico marsh plant species, $A$. germinans and $B$. maritima, to weathered $D W H$ oil. Impacts of oiling to short-term, but not integrated, growth responses were discernible for $A$. germinans, whereas both short-term and integrated growth responses in $B$. maritima were clearly impacted by oiling. Importantly, these findings not only confirm the relatively high tolerance of $A$. germinans seedlings to $D W H$ oiling recently documented by Hughes et al. (2018) but also refines the oiling dosages $\left(1,2\right.$, and $\left.4 \mathrm{~L} \mathrm{~m}^{-2}\right)$ at which this tolerance can be anticipated. Additionally, this study elucidates hitherto unknown $D W H$ oiling exposure growth responses for Batis maritima, an important subdominant high marsh species in the Gulf of Mexico. This research also corroborates prior studies (e.g., Meudec et al. 2007; Lin and Mendelssohn 2012) suggesting that, when in isolation, soil oiling is often more detrimental to plant growth than tissue oiling. These findings enhance the existing knowledge base on which estimates of the likely severity of oil spills to Gulf of Mexico coastal plant community are based.

In a similar study, Hughes et al. (2018) applied $8 \mathrm{~L} \mathrm{~m}^{-2}$ of Louisiana Sweet crude oil weathered with a bubbler aerator for 5 days to outdoor mesocosms containing either $A$. germinans, $S$. alterniflora, or a mixed planting of the two and compared these to untreated mesocosms. The oil application was repeated and drained daily for 5 days, and a diurnal tidal regime was simulated throughout the one-year experimental duration. Similar to the findings presented herein, Hughes et al. (2018) detected no effect of oiling on A. germinans stem height. Further, a consistent negative impact of oiling was not detected for crown volume, a metric representative of $A$, germinans aboveground growth by Hughes et al. (2018), which is consistent with the lack of impacts to $A$. germinans aboveground biomass reported here. Interestingly, reductions to $A$. germinans leaf number were detected with oiling application, but only after a full year of growth under oiled conditions; no impact of oiling to leaf number was detected at the three, seven, or nine month measurement periods (Hughes et al. 2018). Although no effect of oiling on $A$. germinans leaf number was found in the present assessment, the experimental duration was approximately four months, making the findings commensurate between the studies. Importantly, although no effect of oiling on $A$. germinans belowground biomass was found in this study, a reduction in belowground biomass with oiling was reported by Hughes et al. (2018). This again likely reflects the substantial difference in study duration (4 months versus 12 months), and also the higher oil dosage ( $8 \mathrm{~L}$ $\mathrm{m}^{-2}$ ) used by Hughes et al. (2018) compared to this study $\left(4 \mathrm{~L} \mathrm{~m}^{-2}\right)$.

Other studies assessing the survival and growth of $A$. germinans when exposed to oils other than weathered $D W H$ oil reveal a range of responses. For instance, all $A$. germinans seedlings died within a few 
weeks of being planted in sediment oiled with a $12 \mathrm{~L} \mathrm{~m}^{-2}(120 \mathrm{~mL}$ in the experiment) of fresh lubricating oil (Proffitt et al. 1995). Similarly, application of $120 \mathrm{~mL}$ of Bonny Light crude oil to the base of $A$. germinans seedlings resulted in lower stem height and stem diameter compared to the control over a 16 week study and impacts with respect to leaf length, leaf width, leaf production, leaf senescence, and seedling survival beginning in the third week (Chindah et al. 2011). Although, the experiment reported herein did not indicate such impacts, it employed a weathered oil that would be expected to exhibit reduced toxicity (Grant et al. 1993; Mendelssohn et al. 2012) at lower soil oiling levels Getter et al. (1983) found that unweathered Bunker $\mathrm{C}$ fuel oil, No. 2 fuel oil, and light Arabian crude oil applied in dosages of $12.5 ; 25 ; 250 ; 2,500$; and $25,000 \mu \mathrm{L}$, to $A$. germinans seedlings demonstrated decreased leaf width with each oil type and at each dose, with a threshold effect on new foliage detected at 2,500 $\mu \mathrm{L}$ dosing (Getter et al. 1983). The experiment described herein used weathered crude oil applications in the amounts of 1,$800 ; 3,500 ;$ and $7,100 \mu \mathrm{L}$. Although the amounts applied to soil in this study are comparable to those of Getter et al. (1983), the lower toxicity of the weathered oil that was employed likely explains the lack of detection of similar impact.

Oiling impacts to $B$. maritima were detected for multiple growth indicators, indicating that $B$. maritima has a greater sensitivity to weathered $D W H$ oiling than $A$. germinans seedlings. Soil oiling of $4 \mathrm{~L} \mathrm{~m}^{-2}$ exhibited lower cumulative stem height, lower total aboveground biomass, and lower live aboveground biomass than the control for B. maritima, and the interaction of $4 \mathrm{~L} \mathrm{~m}^{-2}$ soil oiling and $100 \%$ tissue oiling revealed lower $B$. maritima total aboveground biomass, live aboveground biomass, and belowground biomass than the control. Although not statistically significant, similar trends were also notable, including reduced growth of $B$. maritima stem diameter under $100 \%$ tissue oiling and increased visual chlorosis with $4 \mathrm{~L} \mathrm{~m}^{-2}$ soil oiling.

A tanker spill of 75,000 to 150,000 gallons of crude oil-water emulsion, which affected 30 miles of shoreline along the Florida Keys, was observed to result in mortality of Batis spp. in areas where substrate, stems, or leaves were coated with the contaminant (Irwin et al. 1997). Although the current controlled study did not result in complete mortality of $B$. maritima significant impacts to growth processes were detected with soil and tissue oiling. Tunnell et al. (1995) examined regrowth of vegetation following oil contamination from a ruptured pipeline in the high marsh at Upper Copano Bay, Texas, and the subsequent burning of oil that remained after oil recovery processes. Distichlis spicata was the primary recolonizer. Secondary succession by climactic perennial species, such as $B$. maritima, showed a trend, though slow and insignificant, for increasing frequency over time. Batis maritima demonstrated an average frequency of $3.1 \%$ in the impacted areas and $9.8 \%$ in the control areas during the study period of between about 1 and 2.5 years following the spill. The species was shown to contribute to regrowth following oil contamination, recovery techniques, and burning, but it did so slowly and without full recovery of frequency over the time examined.

\section{Conclusions}


The current examination of soil and tissue oiling with weathered MC252 did not detect deleterious impacts to the growth of $A$. germinans seedlings but did reveal that some growth responses of $B$. maritima were adversely affected at greater levels of exposure, with lower cumulative stem height at $4 \mathrm{~L}$ $\mathrm{m}^{-2}$ of soil oiling and lower total aboveground biomass, live aboveground biomass, and belowground biomass with the interaction of $4 \mathrm{~L} \mathrm{~m}^{-2}$ soil oiling and $100 \%$ tissue oiling. The tolerance of $A$. germinans suggests that it may survive and play an integral role in recovery of coastlines contaminated by crude oil spills. The detection of negative effects on B. maritima growth with higher levels of oiling are consistent with field observations of oiling impacts to areas where this species occurs. However, the apparent absence of impacts to Batis maritima with lower levels of weathered crude oil contamination implies that this species, also, can contribute to spill recovery at lower levels of pollution. These findings provide novel insights into the likely impacts to Gulf of Mexico high marsh habitats under possible future oiling scenarios.

\section{Declarations}

\section{Ethics approval and consent to participate}

Not applicable

\section{Consent for publication}

Not applicable

\section{Availability of data and materials}

The datasets used and analyzed during the current study are available from the corresponding author on reasonable request

\section{Competing interests}

The authors declare they have no competing interests

\section{Funding}

This research was supported internally by the Applied Plant Science Laboratory at Nicholls State University

\section{Authors' contributions}

JW conceived the research; WH set up and executed the study, and performed data collection; WH and JW equally contributed to statistical analysis and interpretation and the writing of the manuscript

\section{Acknowledgements}


The authors are grateful to Dr. Quenton Fontenot for use of the Nicholls State University Farm Facility for housing the research

\section{References}

Algoni DM (2012) Carbon sequestration in mangrove forests. Carbon Management 3:313-322.

Alleman LK, Hester MW (2010) Refinement of the fundamental niche of black mangrove (Avicennia germinans) seedlings in Louisiana: applications for restoration. Wetlands Ecology Management 19:4760 .

Alleman LK, Hester MW (2011) Reproductive ecology of black mangrove (Avicennia germinans) along the Louisiana coast: propagule production cycles, dispersal limitations, and establishment elevations. Estuaries and Coasts 34:1068.

Ameen F, Hadi S, Moslem M, Al-Sabri A, Yassin MA. (2015) Biodegradation of engine oil by fungi from mangrove habitat. The Journal of General and Applied Microbiology 61:185-192.

Anderson CJ, Hess TA (2012) The effects of oil exposure and weathering on black-needle rush (Juncus roemerianus) marshes along the Gulf of Mexico. Marine Pollution Bulletin 64:2749-2755.

Barbier EB, Hacker SD, Kennedy C, Koch EW, Stier AC, Silliman BR (2011) The value of estuarine and coastal ecosystem services. Ecological Monographs 81:169-193.

Barnes SR, Bond C, Burger N, Anania K, Strong A, Weilant S, Virgets S (2017) Economic evaluation of coastal land loss in Louisiana. Journal of Ocean and Coastal Economics 4.

Burns KA, Garrity SD, Levings SC (1993) How many years until mangrove ecosystems recover from catastrophic oil spills? Marine Pollution Bulletin 26:239-248.

Cahoon, DR (2006) A review of major storm impacts on coastal wetland elevations. Estuaries and Coasts 29:889-898.

Chindah AC, Braide SA, Amakiri J, Onokurhefe J (2011) Effect of crude oil on the development of white mangrove seedlings (Avicennia germinans) in the Niger Delta, Nigeria. Polish Journal of Environmental Studies 20:275-284.

Coastal Protection and Restoration Authority of Louisiana (2017) Louisiana's comprehensive master plan for a sustainable coast. Coastal Protection and Restoration Authority of Louisiana. Baton Rouge, LA.

Debez A, Saadaoui D, Slama I, Huchzermeyer B, Abdelly C (2010) Responses of Batis maritima plants challenged with up to two-fold seawater $\mathrm{NaCl}$ salinity. Journal of Plant Nutrition and Soil Science 173:291-299. 
Devaney JL, Lehmann M, Feller IC, Parker JD (2017) Mangrove microclimates alter seedling dynamics at the range edge. Ecology 98:2513-2520.

Donnelly M, Walters L (2014) Trapping of Rhizophora mangle propagules by coexisting early successional species. Estuaries and Coasts 37:1562-1571.

Duke NC (2016) Oil spill impacts on mangroves: recommendations for operational planning and action based on a global review. Marine Pollution Bulletin 109:700-715.

Everard M, Jha RRS, Russell S (2014) The benefits of fringing mangrove systems to Mumbai. Aquatic Conservation: Marine and Freshwater Ecosystems 24:256-274.

Getter CD, Baca BJ (1984) A laboratory approach for determining the effect of oils and dispersants on mangroves. Oil Spill Chemical Dispersants: Research, Experience, and Recommendations. ASTM International.

Getter CD, Ballou TG, Dahlin JA (1983) Preliminary results of laboratory testing of oil and dispersants on mangroves. International Oil Spill Conference 1983:533-533.

Getter CD, Scott GI, Michel J (1981) The effects of oil spills on mangrove forests: a comparison of five oil spill sites in the Gulf of Mexico and the Caribbean Sea. International Oil Spill Conference 1981:535-540.

Giri C, Long J, Tieszen L (2011) Mapping and monitoring Louisiana's mangroves in the aftermath of the 2010 Gulf of Mexico oil spill. Journal of Coastal Research 27:1059-1064.

Gorman D, Turra A (2016) The role of mangrove revegetation as a means of restoring macrofaunal communities along degraded coasts. Science of the Total Environment 566- 567:223-229.

Grant DL, Clarke PJ, Allaway WG (1993) The response of grey mangrove (Avicennia marina (Forsk.) Vierh.) seedlings to spills of crude oil. Journal of Experimental Marine Biology and Ecology 171:273-295.

Hester MW, Spalding EA, Franze CD (2005) Biological resources of the Louisiana coast: Part 1. An overview of coastal plant communities of the Louisiana gulf shoreline. Journal of Coastal Research 134145.

Hester MW, Willis JM, Rouhani S, Steinhoff MA (2016) Impacts of the Deepwater Horizon oil spill on the salt marsh vegetation of Louisiana. Environmental Pollution 216:361-370.

Hoff RZ., Shigenaka G, Henry Jr CB (1993) Salt marsh recovery from a crude oil spill: vegetation, oil weathering, and response. International Oil Spill Conference. American Petroleum Institute.

Houck, M. and R. Neill. (2009) Plants fact sheet for black mangrove (Avicennia germinans (L.) L). USDANatural Resources Conservation Service, Louisiana Plant Materials Center. 
Hughes AR, Cerbrian J, Heck K, Goff J, Hanley TC, Scheffel W, Zerebecki RA (2018) Effects of oil exposure, plant species composition, and plant genotypic diversity on salt marsh and mangrove assemblages. Ecosphere 9:e02207.

Hutchings P, Saenger P. (1987) Ecology of mangroves. Ecology of Mangroves.

Irwin RJ, Van Mouwerik M, Stevens L, Seese MD, Basham W (1997) Environmental Contaminants Encyclopedia Crude Oil Entry. National Park Service Water Resources Division, Water Operation Branch.

Jankowski KL, Tornqvist TE, Fernandes AM (2017) Vulnerability of Louisiana's coastal wetlands to present-day rates of relative sea-level rise. Nature Communications 8:14792.

Kathiresan K, Bingham BL (2001) Biology of mangroves and mangrove ecosystems. Advances in Marine Biology 40:81-251.

Lee SY, Primavera JH, Dahdouh-Guebas F, et al (2014) Ecological role and services of tropical mangrove ecosystems: a reassessment. Global Ecology and Biogeography 23:726-743.

Lin Q, Mendelssohn IA (2012) Impacts and recovery of the Deepwater Horizon oil spill on vegetative structure and function of coastal salt marsh in the northern Gulf of Mexico. Environmental Science \& Technology 46:3737-3743.

Lin Q, Mendelssohn IA, Graham SA, Hou A, Fleeger JW, Deis DR (2016) Responses of salt marshes to oiling from the Deepwater Horizon spill: implications for plant growth, soil surface-erosion, and shoreline stability. Science of the Total Environment 557-558:369-377.

Lonard RI, Judd FW, Summy KR, DeYoe H, Stalter R (2017) The biological flora of coastal dunes and wetlands: Avicennia germinans (L.) L. Journal of Coastal Research 33:191-207.

Lonard RI, Judd FW, Stalter R (2011) The biological flora of coastal dunes and wetlands: Batis maritima C. Linnaeus. Journal of Coastal Research 27:441-449.

Lugo, A.E. and S.C. Snedaker. 1974. The ecology of mangroves. Annual Review of Ecology and Systematics 5:39-64

Mendelssohn IA, Hester MW, Sasser C, Fischel M. (1990) The effect of a Louisiana crude oil discharge from a pipeline break on the vegetation of a southeast Louisiana brackish marsh. Oil \& Chemical Pollution 7:1-15.

Mendelssohn IA, Andersen GL, Baltz DM, et al (2012) Oil impacts on coastal wetlands: implications for the Mississippi River delta ecosystem after the Deepwater Horizon oil spill. BioScience 62:562-574.

Meudec A, Poupart N, Dussauze J, Deslandes E. (2007) Relationship between heavy fuel oil phytotoxicity and polycyclic aromatic hydrocarbon contamination in Salicornia fragilis. Science of the Total 
Michel J, Rutherford N (2013) Oil spills in marshes: planning \& response considerations. Seattle: Office of Response and Restoration, National Oceanic and Atmospheric Administration, Seattle, WA and American Petroleum Institute, Washington, DC.

Milbrandt EC, Tinsley MN (2006) The role of saltwort (Batis maritima L.) in regeneration of degraded mangrove forests. Hydrobiologia 568:369-377.

Mishra DR, Cho HJ, Ghosh S, et al (2012) Post-spill state of the marsh: remote estimation of the ecological impact of the Gulf of Mexico oil spill on Louisiana salt marshes. Remote Sensing of Environment 118:176-185.

Nagelkerken IS, Blaber JM, Bouillon S, et al (2008) The habitat function of mangroves for terrestrial and marine fauna: a review. Aquatic Botany 89:155-185.

Nagi HM, Abubakr MM (2013) Threats status of the mangrove ecosystem along the coastal zone of Yemen. Marine Science 24:101-117.

Naidoo G, Naidoo Y, Achar P (2010) Responses of the mangroves Avicennia marina and Bruguiera gymnorrhiza to oil contamination. Flora 205:357-362.

National Oceanic and Atmospheric Administration (2017) Largest oil spills affecting U.S. waters since 1969. National Oceanic and Atmospheric Administration. Available: www.noaa.gov. retrieved October 2020.

Nixon Z, Zengel S, Baker M, Steinhoff M, Fricano G, Rouhani S, Michel J (2016) Shoreline oiling from the Deepwater Horizon oil spill. Marine Pollution Bulletin 107:170-178.

Osland, MJ, Day RH, Hall CT, Brumfield MD, Dugas JL, Jones WR (2017) Mangrove expansion and contraction at a poleward range limit: climate extremes and land-ocean temperature gradients. Ecology 98:125-137.

Pennings SC, Bertness MD (2001) Salt marsh communities. Marine Community Ecology 289-316.

Peterson JM, Bell SS (2012) Tidal events and salt-marsh structure influence black mangrove (Avicennia germinans) recruitment across an ecotone. Ecology 93:1648-1658.

Peterson JM, Bell SS (2015) Saltmarsh boundary modulates dispersal of mangrove propagules: implications for mangrove migration with sea-level rise. PLoS ONE 10:e0119128.

Pezeshki SR, Hester MW, Lin Q, Nyman JA (2000) The effects of oil spill and clean-up on dominant US Gulf coast marsh macrophytes: a review. Environmental Pollution 108:129-139. 
Pickens CN, Sloey TM, Hester MW (2019) Influence of salt marsh canopy on black mangrove (Avicennia germinans) survival and establishment at its northern latitudinal limit. Hydrobiologia 826:195-208.

Proffitt CE, Devlin DJ, Lindsey M (1995) Effects of oil on mangrove seedlings grown under different environmental conditions. Marine Pollution Bulletin 30:788-793.

Rabinowitz D (1978) Dispersal properties of mangrove propagules. Biotropica 10:47-57.

Rasser MK, Fowler NL, Dunton KH (2013) Elevation and plant community distribution in a microtidal salt marsh of the western Gulf of Mexico. Wetlands 33:575-583.

Rosso PH, Pushnik JC, Lay M, Ustin SL (2005) Reflectance properties and physiological responses of Salicornia virginica to heavy metal and petroleum contamination. Environmental Pollution 137:241-252.

Saintilan N, Wilson N, Rogers K, Rajkaran A, Krauss KW (2014) Mangrove expansion and salt marsh decline at mangrove poleward limits. Global Change Biology 20:147-157.

Sandoval-Castro E, Dodd RS, Riosmena-Rodríguez R, et al (2014) Post-glacial expansion and population genetic divergence of mangrove species Avicennia germinans (L.) Stearn and Rhizophora mangle L. along the Mexican coast. PLoS ONE 9:e93358.

Shapiro K, Khanna S, Ustin SL (2016) Vegetation impact and recovery from oil-induced stress on three ecologically distinct wetland sites in the Gulf of Mexico. Journal of Marine Science and Engineering 4:33.

Silliman BR, van de Koppel J, McCoy MW et al (2012) Degradation and resilience in Louisiana salt marshes after the BP-Deepwater Horizon oil spill. Proceedings of the National Academy of Sciences 109:11234-11239.

Suárez N, Medina E (2005) Salinity effect on plant growth and leaf demography of the mangrove, Avicennia germinans L. Trees 19:722.

Tunnell Jr JW, Hardegree B, Hicks DW (1995) Environmental impact and recovery of a high marsh pipeline oil spill and burn site, upper Copano Bay, Texas. International Oil Spill Conference 1:133-138. American Petroleum Institute.

Turner RE, Rabalais NN, Overton EB et al (2019) Oiling of the continental shelf and coastal marshes over eight years after the 2010 Deepwater Horizon oil spill. Environmental Pollution 252:1367-1376.

Whigham DF, Whigham MC, Feller IC, Rodriguez W, King RS (2009) Ecological characteristics of Batis maritima in Florida and Belize. Smithsonian Contributions to the Marine Sciences 38:491-499.

Willis JM, Hester MW (2015) Impacts of Deepwater Horizon oiling on mangrove marsh habitats in Louisiana: technical memorandum (NS_TR.13). DWH Shoreline NRDA Technical Working Group Report. 
Willis JM, Hester MW, Rouhani S, Steinhoff MA, Baker MC (2016) Field assessment of the impacts of Deepwater Horizon oiling on coastal marsh vegetation of Mississippi and Alabama. Environmental Toxicology and Chemistry 35:2791-2797.

Yespelkis P, Donnelly M (2014) Improving community-based shoreline erosion stabilization projects: impacts of potential nurse plants on red mangrove biomass production and survival. The University of Central Florida Undergraduate Research Journal 7:1-11.

Zengel S, Bernik BM, Rutherford N, Nixon Z, Michel J (2015) Heavily oiled salt marsh following the Deepwater Horizon oil spill, ecological comparisons of shoreline cleanup treatments and recovery. PLoS ONE 10, e0132324.

Zengel S, Michel J (2013) Deepwater Horizon oil spill: salt marsh oiling conditions, treatment testing, and treatment history in northern Barataria Bay, Louisiana (interim report October 2011) NOAA Technical Memorandum NOS OR\&R 42. Seattle, WA. 74 pp. https://repository.library.noaa.gov/view/noaa/380.

\section{Figures}




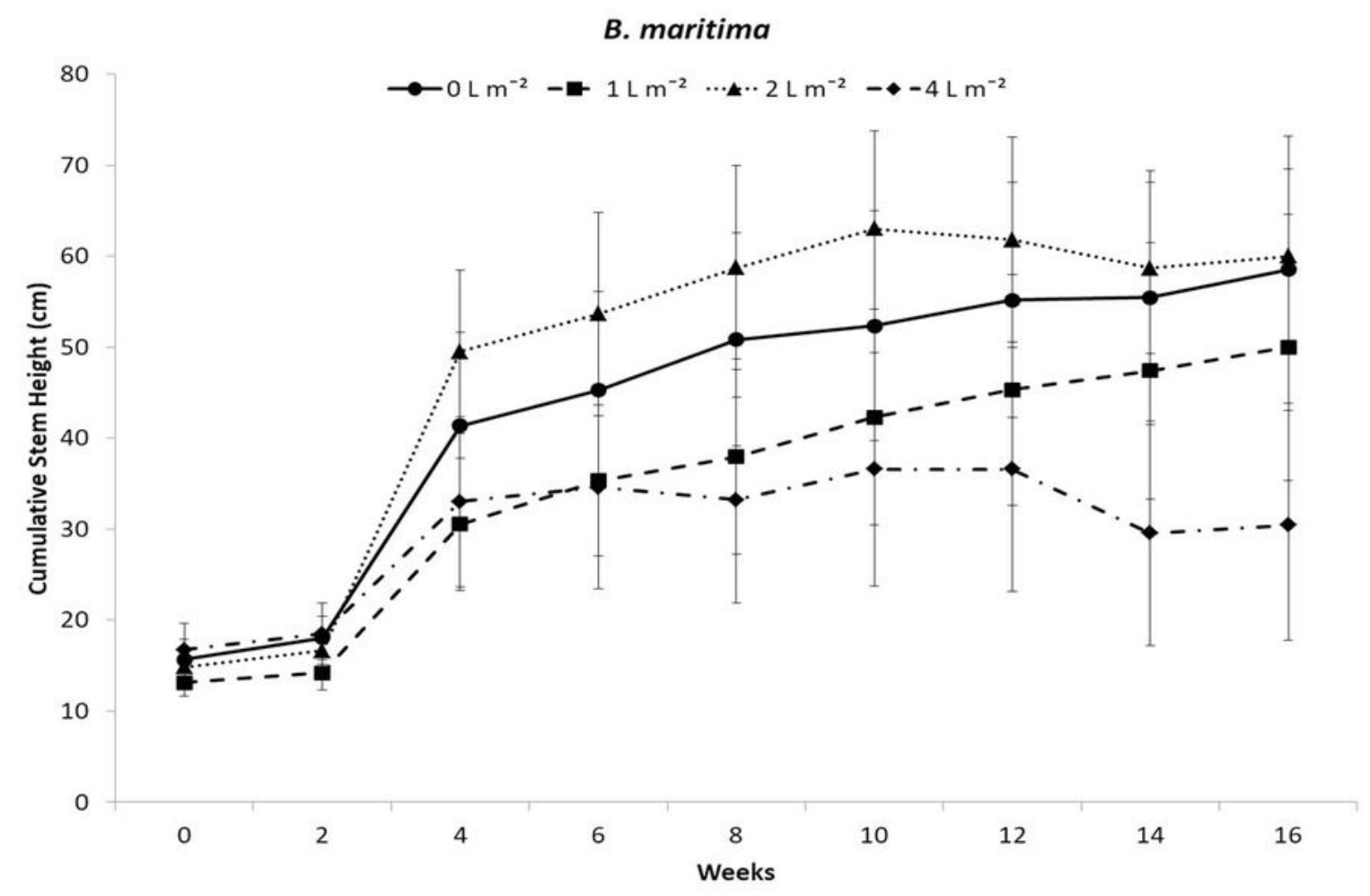

A. germinans

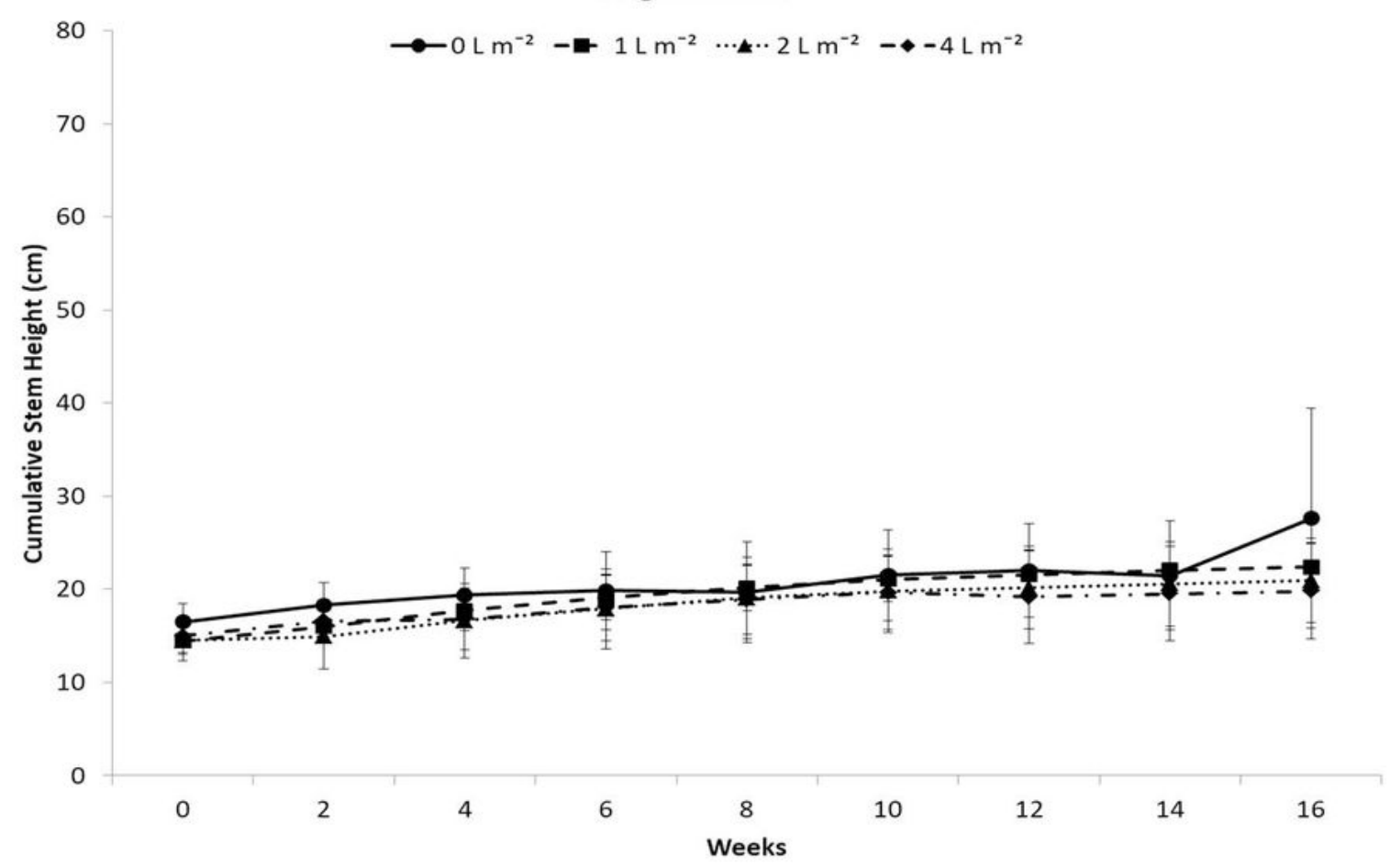

\section{Figure 1}

The effect of sampling period, species, and soil oiling on cumulative stem height, averaged over tissue oiling (mean +/-s.e.) 

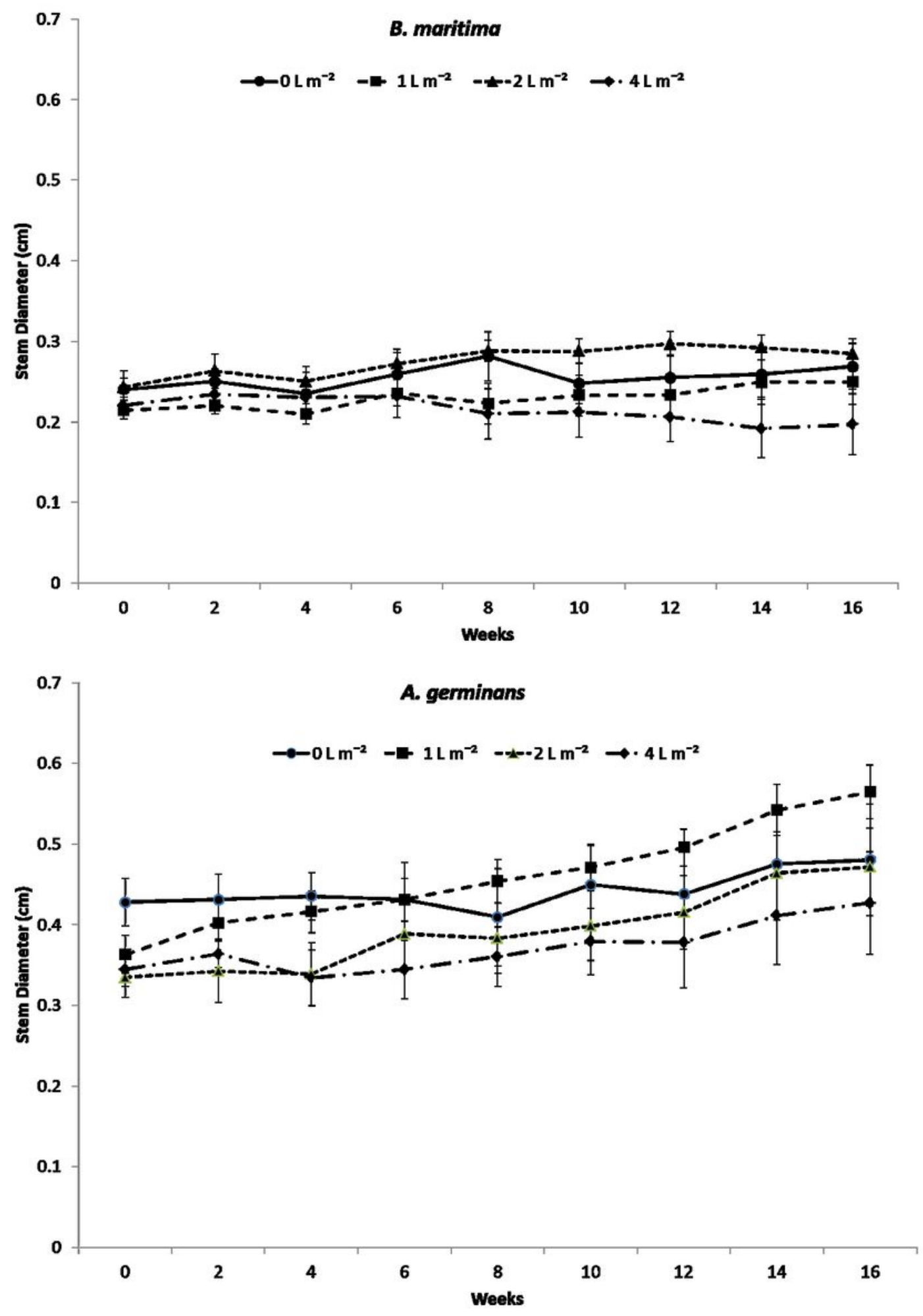

Figure 2

The effect of sampling period, species, and soil oiling on stem diameter, averaged over tissue oiling (mean $+/$ - s.e.) 


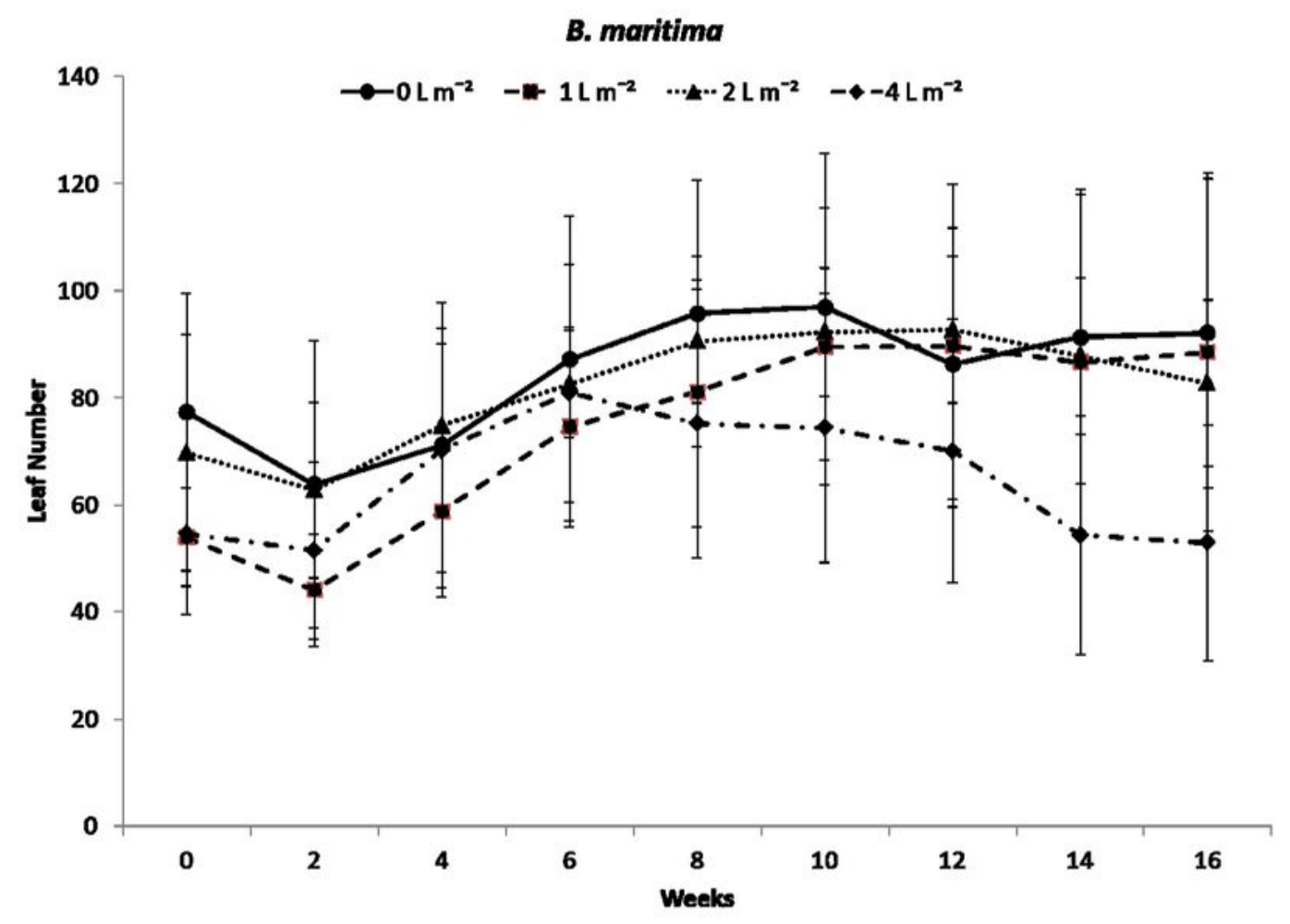

A. germinans

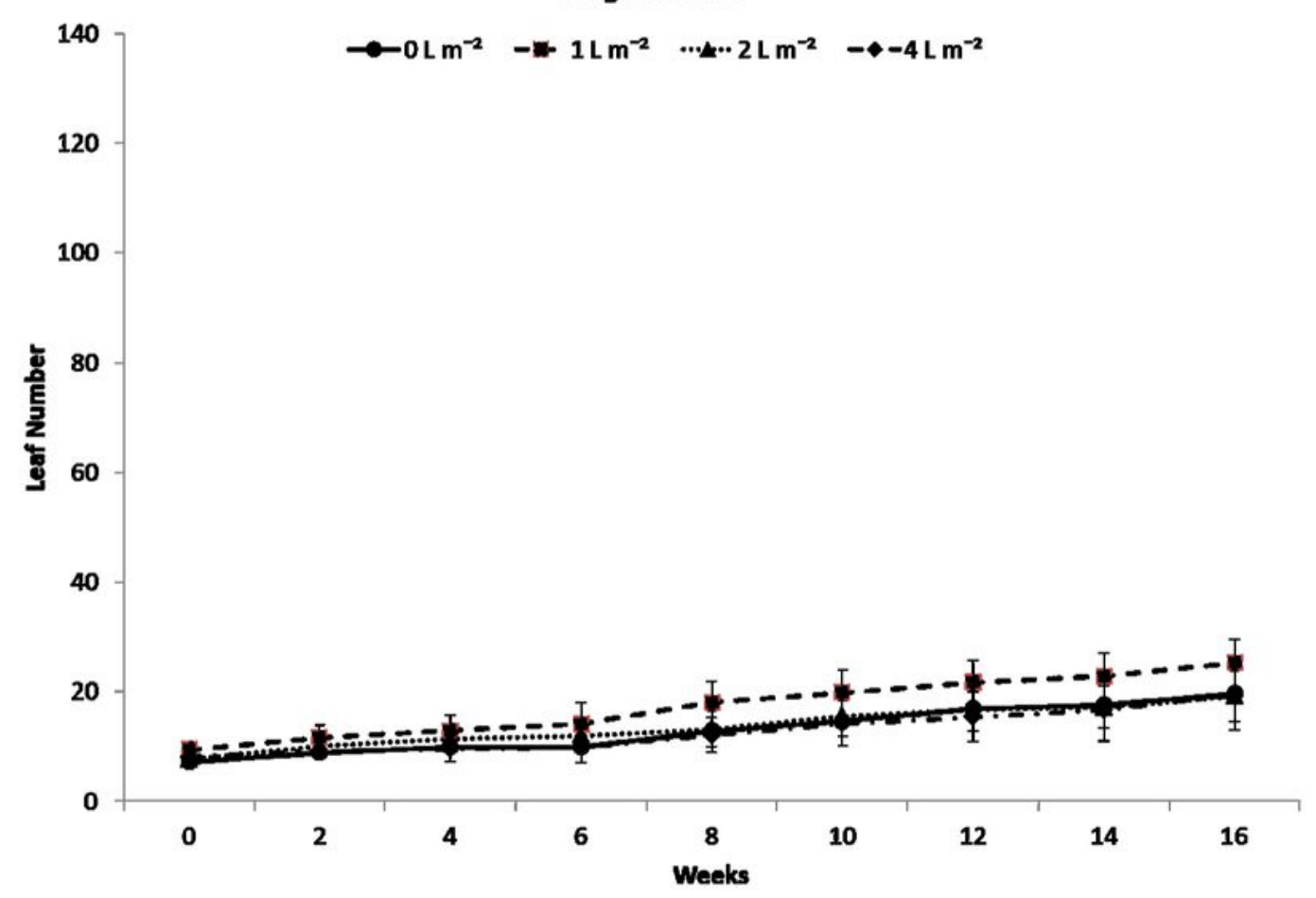

Figure 3

The effect of sampling period, species, and soil oiling on leaf number, averaged over tissue oiling (mean + - s.e.) 


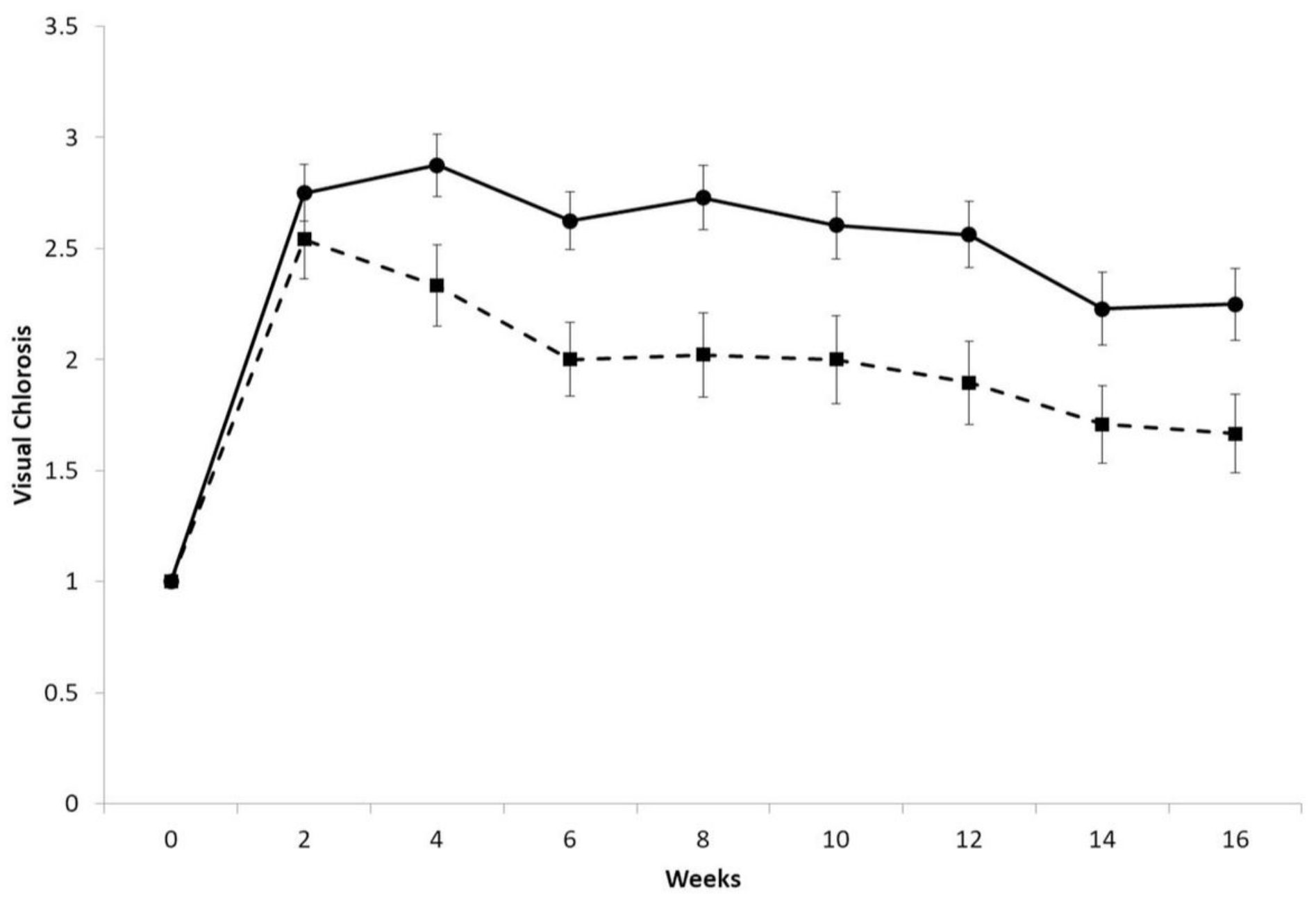

Figure 4

The effect of species and soil oiling level on visual chlorosis over 16 weeks averaged over plant tissue oiling at four soil oiling levels (mean $+/$ - s.e.) 

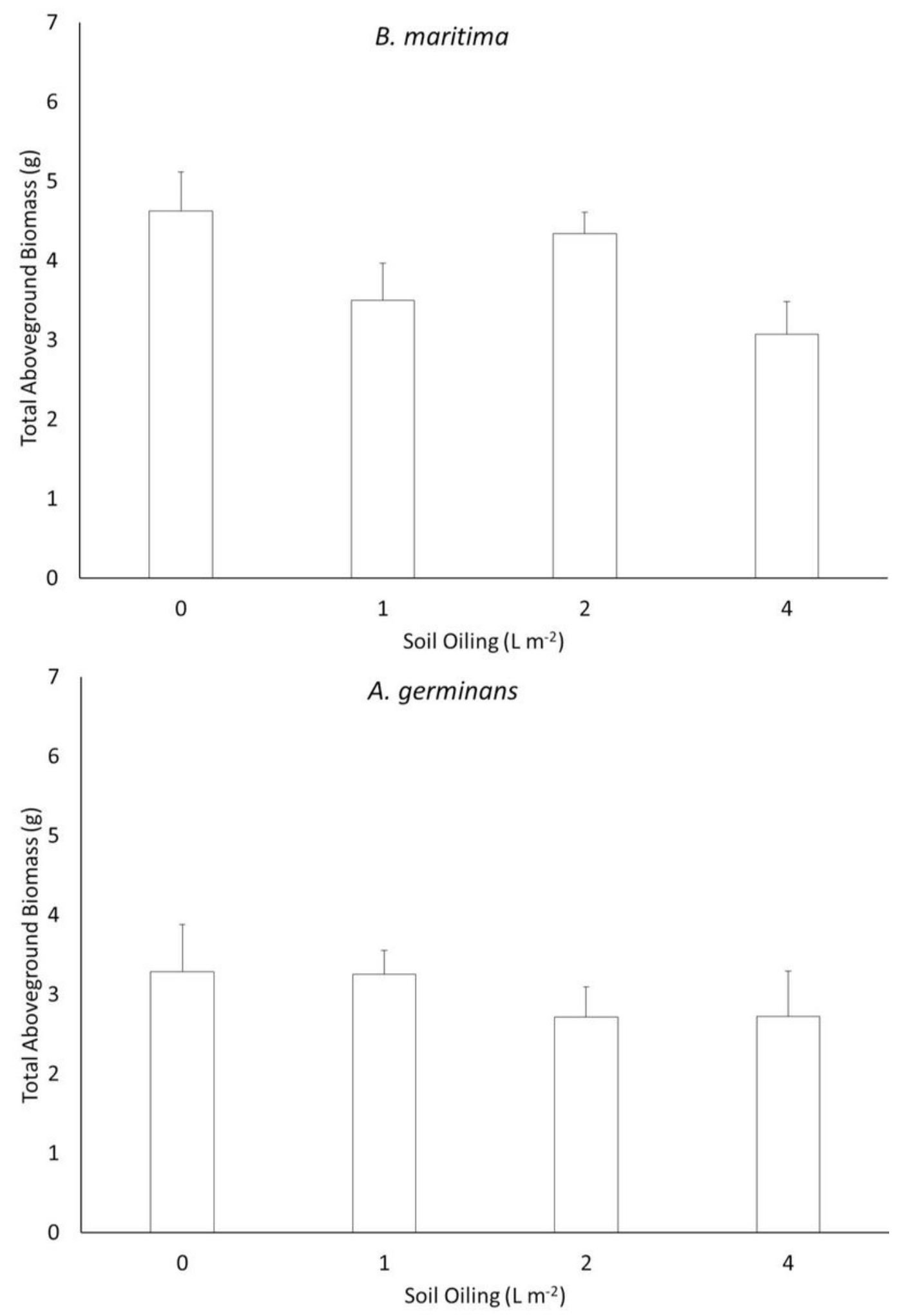

Figure 5

The effect of sampling period, species, and soil oiling on total aboveground biomass, averaged over tissue oiling (mean $+/$ - s.e.) 

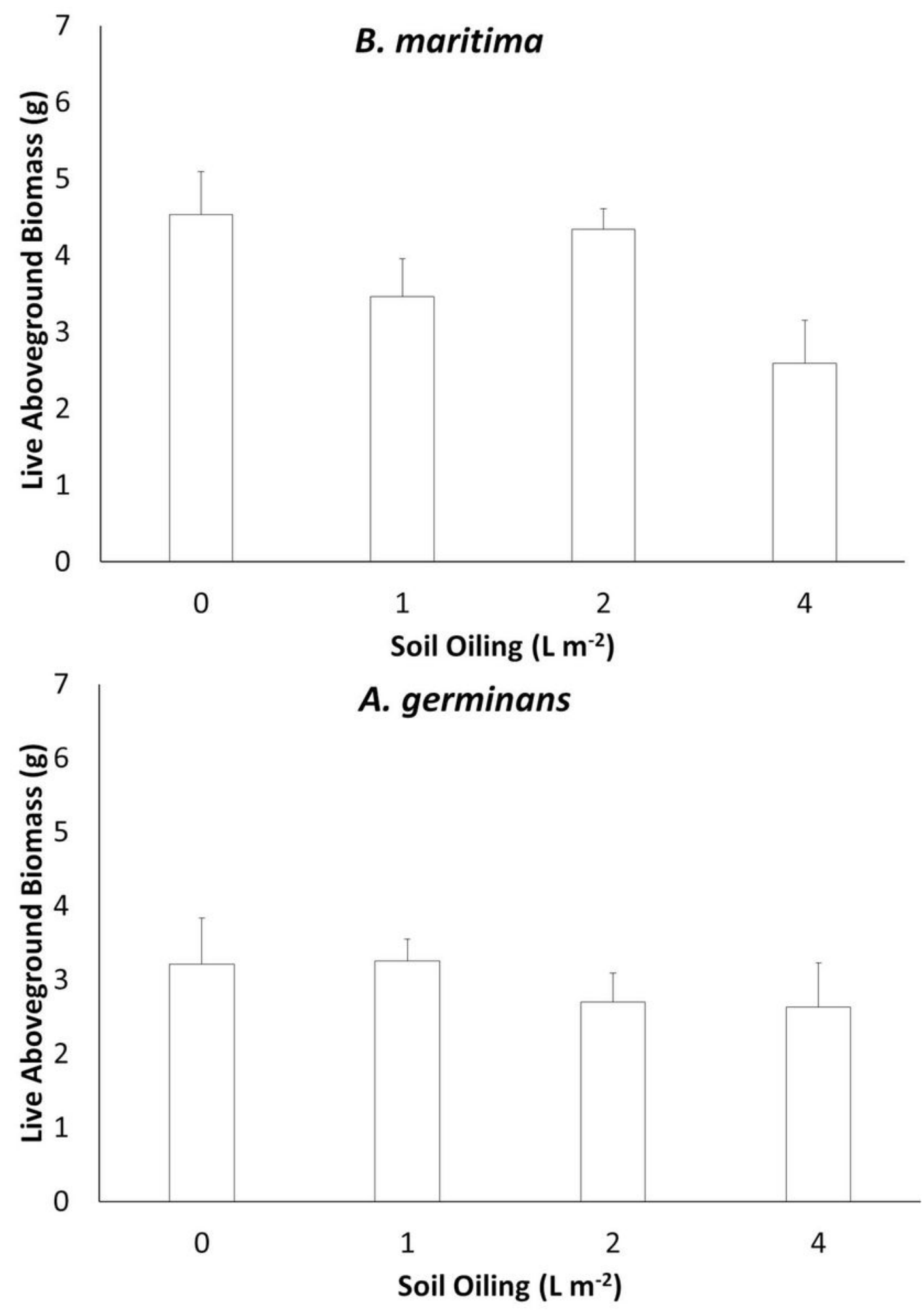

Figure 6

The effect of sampling period, species, and soil oiling on live aboveground biomass, averaged over tissue oiling (mean +/-s.e.) 


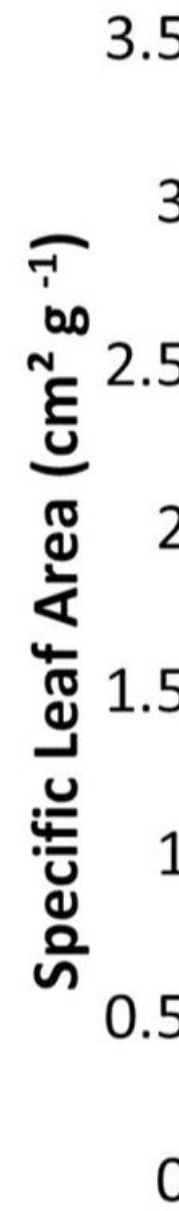

A. germinans

5

3

0

$0 \%$

Figure 7

Effect of tissue oiling on A. germinans specific leaf area averaged across soil oiling (mean +/- s.e.) 